\title{
Eastern Pacific oxygen minimum zones: Supply paths and multidecadal changes
}

\author{
Lothar Stramma, ${ }^{1}$ Gregory C. Johnson, ${ }^{2}$ Eric Firing, ${ }^{3}$ and Sunke Schmidtko ${ }^{1,2}$ \\ Received 10 November 2009; revised 4 May 2010; accepted 12 May 2010; published 14 September 2010.
}

[1] The supply of oxygen-rich water to the oxygen minimum zones (OMZs) of the eastern North and South Pacific via zonal tropical currents is investigated using shipboard acoustic Doppler current profiler and hydrographic section data. Near the equator, the Equatorial Undercurrent (EUC), Northern and Southern Subsurface Countercurrents (SCCs), and the Northern and Southern Intermediate Countercurrents (ICCs) all carry water that is oxygen richer than adjacent westward flows, thereby providing a net oxygen supply to the eastern Pacific OMZs. The synoptic velocity-weighted oxygen concentration difference between eastward and westward flows is typically $10-50 \mu \mathrm{mol} \mathrm{kg}{ }^{-1}$.

Subthermocline zonal oxygen fluxes reflect decreasing oxygen concentrations of the EUC, the SCCs, and the ICCs as they flow eastward. Approximately 30 year time series in well-sampled regions of the equatorial Pacific show oxygen content decreasing as rapidly as $-0.55 \mu \mathrm{mol} \mathrm{kg}^{-1} \mathrm{yr}^{-1}$ in the major oxygen supply paths of the OMZs for a 200-700 m layer and similar trends for a density layer spanning roughly these depths. This finding is in gross agreement with climate models, which generally predict expanding OMZs.

Citation: Stramma, L., G. C. Johnson, E. Firing, and S. Schmidtko (2010), Eastern Pacific oxygen minimum zones: Supply paths and multidecadal changes, J. Geophys. Res., 115, C09011, doi:10.1029/2009JC005976.

\section{Introduction}

[2] Oxygen is a very sensitive indicator of both physical and biological change in the ocean [Joos et al., 2003]. As a consequence, oxygen is a key parameter for better understanding the ocean's role in climate [Keeling and Garcia, 2002]. Volumes of the interior ocean that are relatively poor in oxygen are often called oxygen minimum zones (OMZs). There is no consensus on the oxygen threshold defining an OMZ. When oxygen concentrations drop below $\sim 60$ to $120 \mu \mathrm{mol} \mathrm{kg}^{-1}$ (hypoxic conditions) important mobile macroorganisms are stressed or die.

[3] Horizontally extensive OMZs exist in the eastern tropical Pacific, with the lowest dissolved oxygen values found from about 100 to $900 \mathrm{~m}$ [Karstensen et al., 2008]. The strength, vertical extent, and horizontal extent of these OMZs all decrease westward (Figure 1). OMZ cores are located at about $10^{\circ} \mathrm{S}$ and $10^{\circ} \mathrm{N}$, separated by higher oxygen concentrations in the equatorial region (Figure 1b). Areas with $\mathrm{O}_{2}<1 \mu \mathrm{mol} \mathrm{kg}^{-1}$ are found at 300 to $500 \mathrm{~m}$ in parts of the eastern Pacific, well below the suboxic $\left(\mathrm{O}_{2}<5 \mu \mathrm{mol} \mathrm{kg}{ }^{-1}\right)$ threshold. On the isopycnal $\sigma_{\theta}=26.8 \mathrm{~kg} \mathrm{~m}^{-3}$ (350 to $\left.450 \mathrm{~m}\right)$,

\footnotetext{
${ }^{1}$ Leibniz-Institut für Meereswissenschaften an der Universität Kiel (IFM-GEOMAR), Kiel, Germany.

${ }^{2}$ Pacific Marine Environmental Laboratory, NOAA, Seattle, Washington, USA.

${ }^{3}$ Department of Oceanography, School of Ocean and Earth Science and Technology, University of Hawai'i at Mānoa, Honolulu, Hawaii, USA.

Copyright 2010 by the American Geophysical Union. 0148-0227/10/2009JC005976
}

large areas with $\mathrm{O}_{2}<5 \mu \mathrm{mol} \mathrm{\textrm {kg } ^ { - 1 }}$ are centered at about $12-15^{\circ} \mathrm{N}$ in the eastern North Pacific and $5-12^{\circ} \mathrm{S}$ in the eastern South Pacific (Figure 2b). Lowest oxygen concentrations south of the equator are found beneath the Peru Current off northern Peru and north of the equator beneath the eastern Pacific warm pool off the coast of SW Mexico [Fiedler and Talley, 2006]. Similar OMZs exist in the eastern Atlantic, but they are not suboxic, having relatively high minimum dissolved oxygen concentration values: about $40 \mu \mathrm{mol} \mathrm{kg}^{-1}$ in the North Atlantic and $20 \mu \mathrm{mol} \mathrm{kg}^{-1}$ in the South Atlantic.

[4] A prominent feature of ventilated thermocline models [Luyten et al., 1983] is the poleward deflection of streamlines toward the eastern boundary in the equatorward limbs of the subtropical gyres. This pattern leaves unventilated tropical shadow zones extending westward from the eastern boundary between the equatorward edges of the subtropical gyres. The predicted shadow zones roughly coincide with the tropical OMZs and with maxima in CFC-derived water age [Fine et al., 2001, Figure 4]. Hence a direct supply of oxygen from the subtropical gyres to the OMZs is blocked, leaving eastward tropical currents as the most likely lateral advective sources of oxygen to the OMZs. In the Atlantic, the North Equatorial Countercurrents and the North Equatorial Undercurrent have been identified as supplying relatively oxygen-rich water to the North Atlantic OMZ [Stramma et al., 2008a]. Here we assess which of the many zonal currents in the tropical Pacific may resupply the Pacific OMZs.

[5] Since the OMZs primarily lie below the pycnocline, we focus on eastward currents with subpycnocline expressions. However, the upper bounds of the OMZs do lie in the 

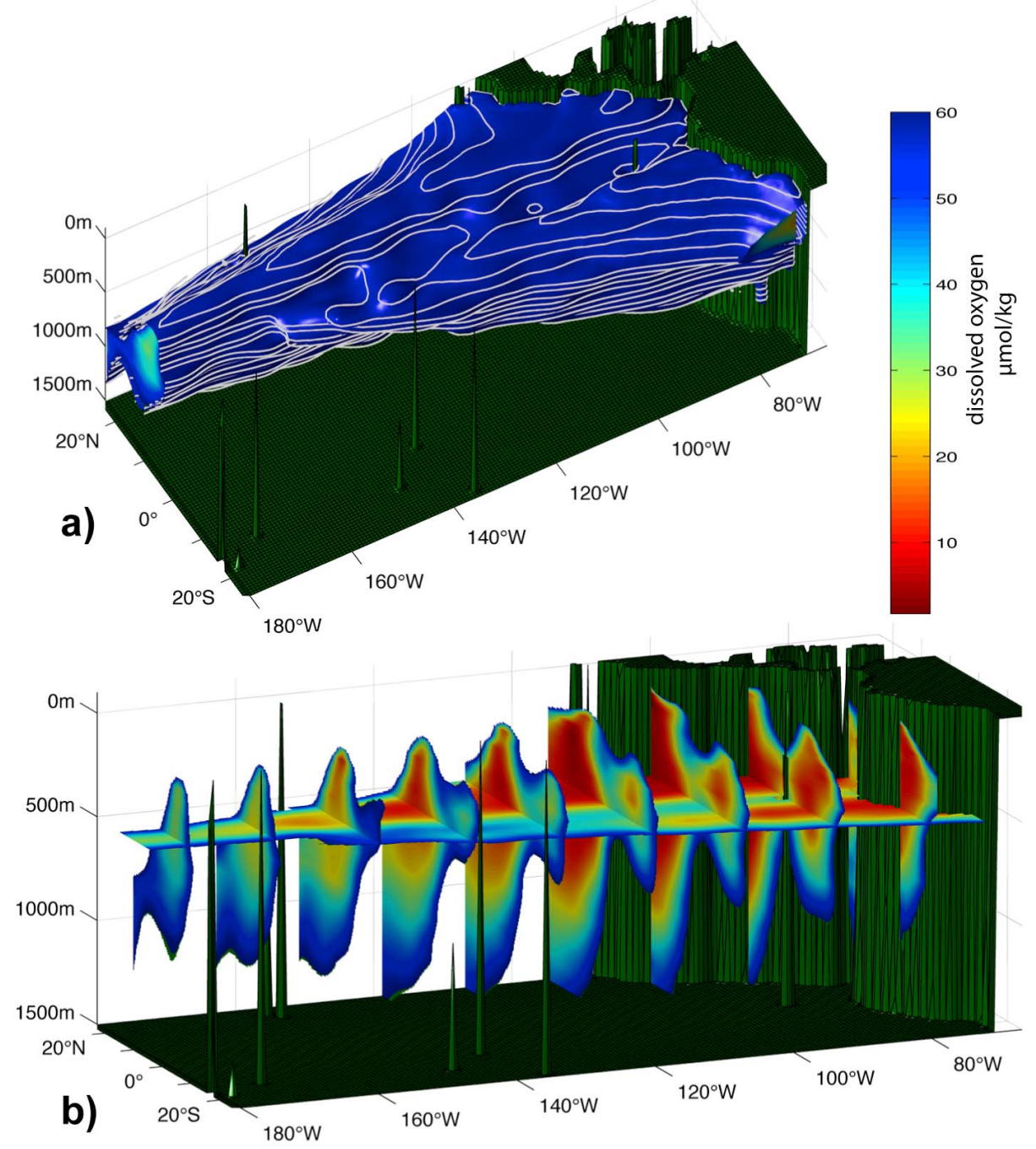

Figure 1. Three-dimensional visualizations of the North and South Pacific eastern oxygen-minimum zones (OMZs) displaying (a) the $60 \mu \mathrm{mol} \mathrm{kg}^{-1}$ oxygen isosurface with $50 \mathrm{~m}$ depth contours as white lines and (b) vertical and horizontal slices with oxygen concentrations $<60 \mu \mathrm{mol} \mathrm{kg}^{-1}$ color shaded as indicated in the bottom color bar. Database is the World Ocean Atlas $20051^{\circ}$ mean climatology.

density range of the Subtropical Cells. These cells connect the subtropical subduction regions of both hemispheres to the eastern, equatorial upwelling regimes by equatorward thermocline and poleward surface flows, together with lowlatitude eastward currents [Schott et al., 2004]. The most germane of these eastward currents are discussed below.

[6] The most prominent eastward current with a subpycnocline expression is the Equatorial Undercurrent (EUC) (Figure 2), which flows eastward along the equator across the entire Pacific [Johnson et al., 2002] carrying relatively oxygen-rich water [Wyrtki and Kilonsky, 1984]. A westward Equatorial Intermediate Current (EIC) is often found below the EUC in the western Pacific. The Pacific subsurface countercurrents (SCCs, also known as Tsuchiya jets in the Pacific and as the North and South Equatorial Undercurrents in the Atlantic) [Tsuchiya, 1975] are narrow eastward currents that bracket the equator just below the equatorial thermocline. (The terms thermocline and pycnocline, or thermostad and pycnostad, are used interchangeably here, depending on historical context, since salinity plays a small role in stratifying the tropical Pacific.) Deeper, denser, and weaker than the EUC, the SCCs form the poleward boundaries of the $13^{\circ} \mathrm{C}$ equatorial thermostad discussed below. The northern SCC (NSCC) and the southern SCC (SSCC), also referred to as the NSSCC and SSSCC [Kessler, 2006], start around $3^{\circ}$ from the equator in the western Pacific, then gradually diverge and shoal to the east, with cores around $6^{\circ}$ from the equator and $150 \mathrm{~m}$ below the surface by $110^{\circ} \mathrm{W}$ [Johnson and Moore, 1997; Rowe et al., 2000]. Another eastward current, the Secondary SSCC, is found poleward of the SSCC and extending to greater densities [Rowe et al., 2000]. No North Pacific counterpart to the Secondary SSCC has been identified. Firing et al. [1998] described a westward South Equatorial Intermediate Current (SEIC) and a North Equatorial Intermediate Current (NEIC) centered around $500 \mathrm{~m}$ and $3^{\circ}$ from the equator. Even deeper, denser, and weaker eastward current extrema (North and South Intermediate Countercurrents; SICC, NICC) are found at 

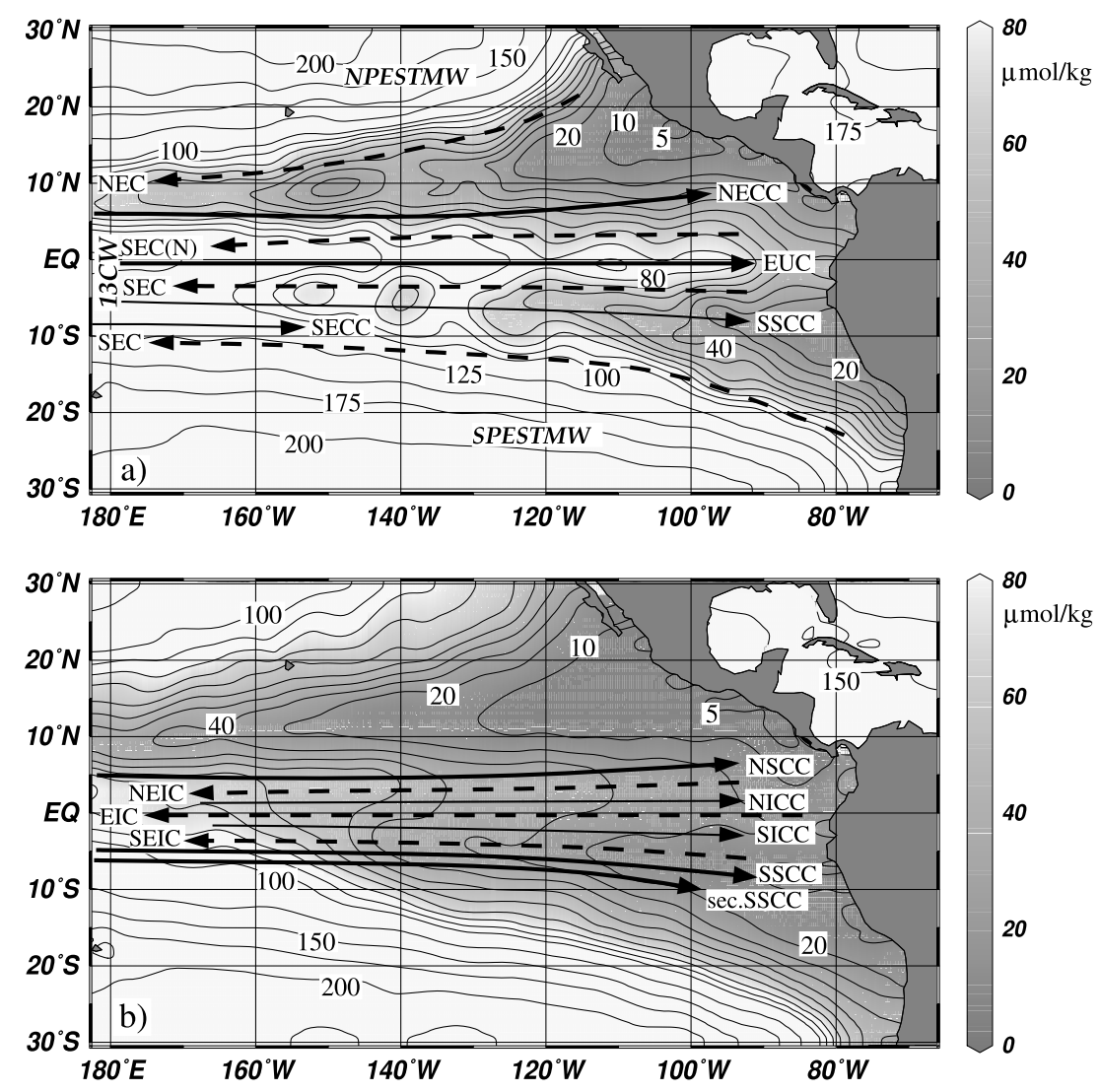

Figure 2. Eastern tropical Pacific distribution of mean dissolved oxygen on (a) $\sigma_{\theta}=26.3 \mathrm{~kg} \mathrm{~m}^{-3}$, located at about $150-300 \mathrm{~m}$, and (b) $\sigma_{\theta}=26.8 \mathrm{~kg} \mathrm{~m}^{-3}$, located at about 350-450 m. Contours are shown for $5 \mu \mathrm{mol} \mathrm{kg}{ }^{-1}$ at $10 \mu \mathrm{mol} \mathrm{kg}-1$ increments from 10 to $100 \mu \mathrm{mol} \mathrm{kg}-1$ and at $25 \mu \mathrm{mol} \mathrm{kg}^{-1}$ increments for values above $100 \mu \mathrm{mol} \mathrm{kg}^{-1}$. World Ocean Atlas 2005 mean climatology is plotted using Ocean Data View software (R. Schlitzer, 2007; available at http://odv.awi.de). Currents indicated for the near surface layers (Figure 2a) and the subpycnocline layers (Figure 2b) include the North Equatorial Current (NEC), the North Equatorial Countercurrent (NECC), the northern and main branches of the South Equatorial Current (SEC(N) and SEC), the Equatorial Undercurrent (EUC), the Northern and Southern Subsurface Countercurrents (NSCC and SSCC), the South Equatorial Countercurrent (SECC), the North and South Intermediate Currents (NICC and SICC), the Equatorial Intermediate Countercurrent (EIC), the North and South Equatorial Intermediate Currents (NEIC and SEIC) as well as the secondary band of the SSCC (sec. SECC). These currents are not necessarily found exactly on the two isopycnals shown. For their typical vertical locations see Figures 3-7. Schematic locations of $13^{\circ} \mathrm{C}$ Equatorial Water $(13 \mathrm{CW})$ and the South and North Pacific Eastern Subtropical Mode Water (SPESTMW and NPESTMW) are also indicated. The NEC and SEC carry NPESTMW and SPESTMW westward, while in the eastern shadow zones containing modified 13CW [Fiedler and Talley, 2006] not much exchange takes place.

about $2^{\circ}$ from the equator from 500 to $1500 \mathrm{~m}$ [Firing et al., 1998]. These intermediate countercurrents could also supply oxygen to the OMZs.

[7] The sources, variability, and fate of many of these currents remain unresolved. For instance, there is evidence that part of the EUC flows southeast into the Peru Undercurrent and contributes to the coastal upwelling, but observations are sparse [Kessler, 2006, and references therein]. The Galapagos Islands at and just south of the equator at $90-92^{\circ} \mathrm{W}$ are a topographic barrier for the EUC and for the westward flowing South Equatorial Current (SEC) [Eden and Timmermann, 2004], complicating the currents in the eastern equatorial Pacific. The density of the SCCs decreases substantially to the east, indicating some unknown combination of diapycnal flow and lateral exchange with westward recirculations [Rowe et al., 2000].

[8] South of the equator the surface-intensified South Equatorial Countercurrent is weak and found mainly in the western Pacific [e.g., Eldin, 1983] and distinct from the SSCC. In contrast, north of the equator, the NSCC is connected to the North Equatorial Countercurrent (NECC). A boundary between these two currents has been set at $\sigma_{\theta}=$ $25.0 \mathrm{~kg} \mathrm{~m}^{-3}$ in the eastern Pacific [Hayes et al., 1983]. The NSCC and the SSCC cores lie within the neutral density range $26.2<\gamma_{\mathrm{n}}<26.5 \mathrm{~kg} \mathrm{~m}^{-3}$ in the eastern Pacific [Rowe et al., 2000]. (Here we use $\sigma_{\theta}$, which is close to $\gamma_{\mathrm{n}}$ in the region of interest; the depth of $26.2 \mathrm{~kg} \mathrm{~m}^{-3}$ for these quantities is the same within a few meters, and for $26.5 \mathrm{~kg} \mathrm{~m}^{-3} \sigma_{\theta}$ is deeper than $\gamma_{\mathrm{n}}$ by as much as $30 \mathrm{~m}$. Hence our analysis 


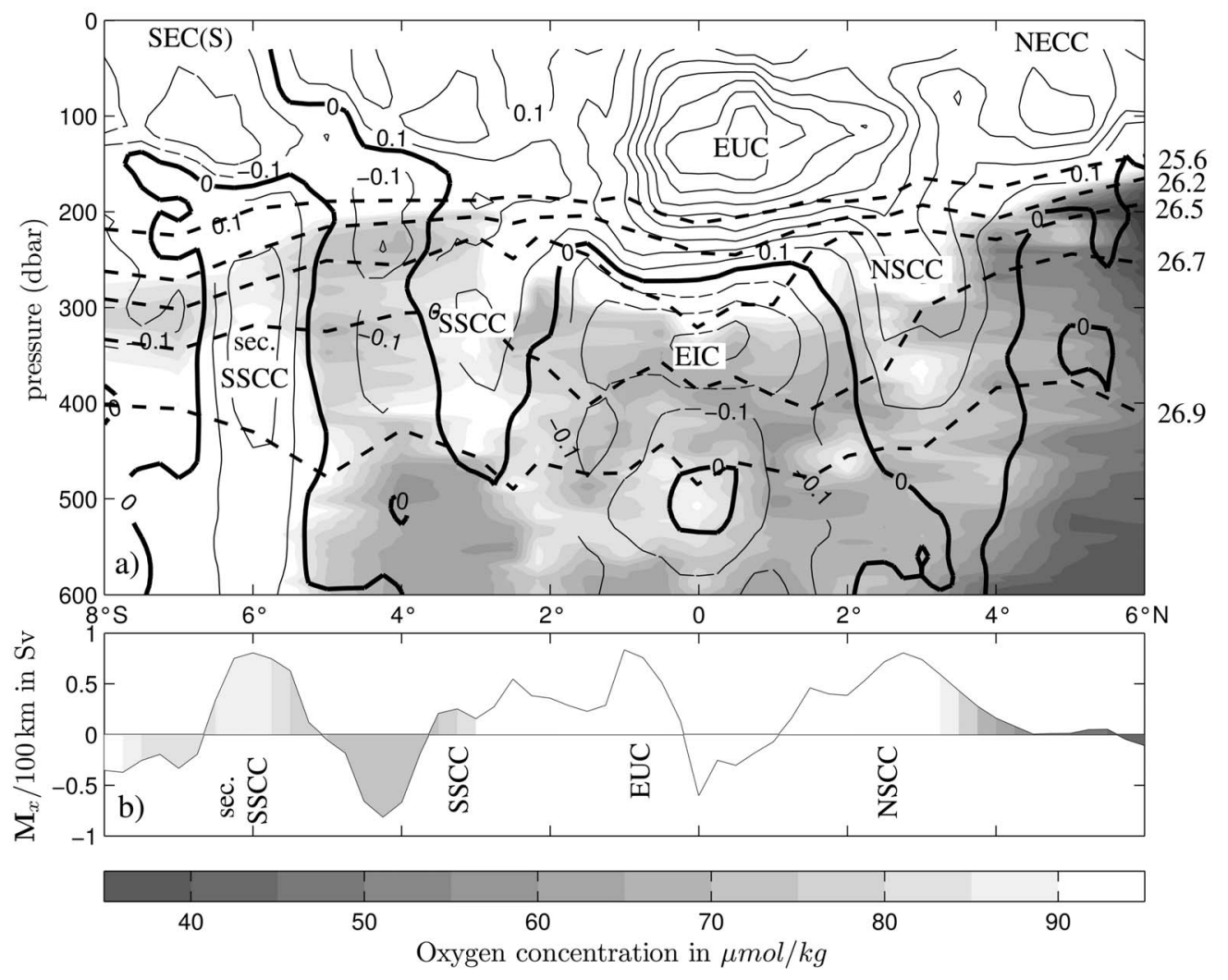

Figure 3. (a) Oxygen distribution (gray shading for 35-90 $\mu \mathrm{mol} \mathrm{kg}^{-1}$ ), selected isopycnals (dashed lines), and ADCP-measured zonal velocity (black contours at $0.1 \mathrm{~m} \mathrm{~s}^{-1}$ intervals, positive eastward) along $170^{\circ} \mathrm{W}$ in July 2004. The southern branch of the South Equatorial Current (SEC(S)), the Equatorial Undercurrent (EUC), the Southern and Northern Subsurface Countercurrent (SSCC and NSCC), the North Equatorial Countercurrent (NECC), and the North Equatorial Intermediate Current (NEIC) are indicated. (b) Transport in $\mathrm{Sv}(100 \mathrm{~km})^{-1}$ for $26.2<\sigma_{\theta}<26.5 \mathrm{~kg} \mathrm{~m}^{-3}$, gray shaded by the layer mean oxygen concentration.

covers a slightly larger depth interval than that of Rowe et al. [2000].) The climatological oxygen distribution on $\sigma_{\theta}=$ $26.3 \mathrm{~kg} \mathrm{~m}^{-3}$ (about 150 to $300 \mathrm{~m}$ ) (Figure 2a), near the NSCC and SSCC cores, shows no enhanced values at the latitudes of the SCCs (3-6 from the equator). The spatial smoothing and temporal averaging in the climatology may mask the narrow structure associated with the Pacific SCCs. Similar plots in the Atlantic, however, (not shown) do contain a hint of oxygen-rich structure associated with the SCCs.

[9] The OMZ is influenced by several water masses. The oxygen-rich surface waters lie atop the OMZ and contrast with it. The Subtropical Underwater (STUW) carried eastward into the upper OMZs by the EUC is also relatively oxygen-rich compared to the $\mathrm{OMZ}$. The $13^{\circ} \mathrm{C}$ Equatorial Water (13CW) [Montgomery and Stroup, 1962] and the South and North Pacific Eastern Subtropical Mode Water (SPESTMW, NPESTMW) [Hanawa and Talley, 2001; Wong and Johnson, 2003] all move eastward in the deep EUC and SCC's, carrying oxygen-richer water to the OMZ. The Antarctic Intermediate Water (AAIW), oxygen richer than the North Pacific Intermediate Water (NPIW) [Wijffels et al., 1996] is also carried eastward in the deeper reaches of the SCC's and the ICC's.

[10] Climate and biogeochemical models predict an overall decline in ocean dissolved oxygen concentrations and a consequent expansion of OMZs under global warming conditions [Matear and Hirst, 2003; Oschlies et al., 2008]. Only a few reports of multidecadal ocean oxygen changes have been made, however. For example, declining oxygen concentrations have been observed in the interior waters of the eastern subarctic Pacific at Ocean Station Papa $\left(50^{\circ} \mathrm{N}\right.$, $145^{\circ} \mathrm{W}$ ) [Whitney et al., 2007] as well as for several subtropical areas in all oceans [Emerson et al., 2004, Table 1]. Long records of dissolved oxygen are sparser in the tropical Pacific than at higher latitudes. Recently Stramma et al. [2008b] described declining oxygen concentrations in the low-oxygen layers of all tropical oceans. Here we investigate the supply routes of oxygen-rich water to the OMZs of the eastern North and South Pacific, estimate zonal subthermocline oxygen fluxes for the equatorial Pacific between $8^{\circ} \mathrm{S}$ and $8^{\circ} \mathrm{N}$ in isopycnal layers as well as for some of the currents that supply oxygen to the OMZs, and present oxygen time series for some equatorial areas with sampling sufficient to describe multidecadal changes.

\section{Instruments and Methods}

\subsection{Hydrographic and Shipboard ADCP Data}

[11] Shipboard hydrographic and current observations from meridional cross-equatorial sections occupied by the World 


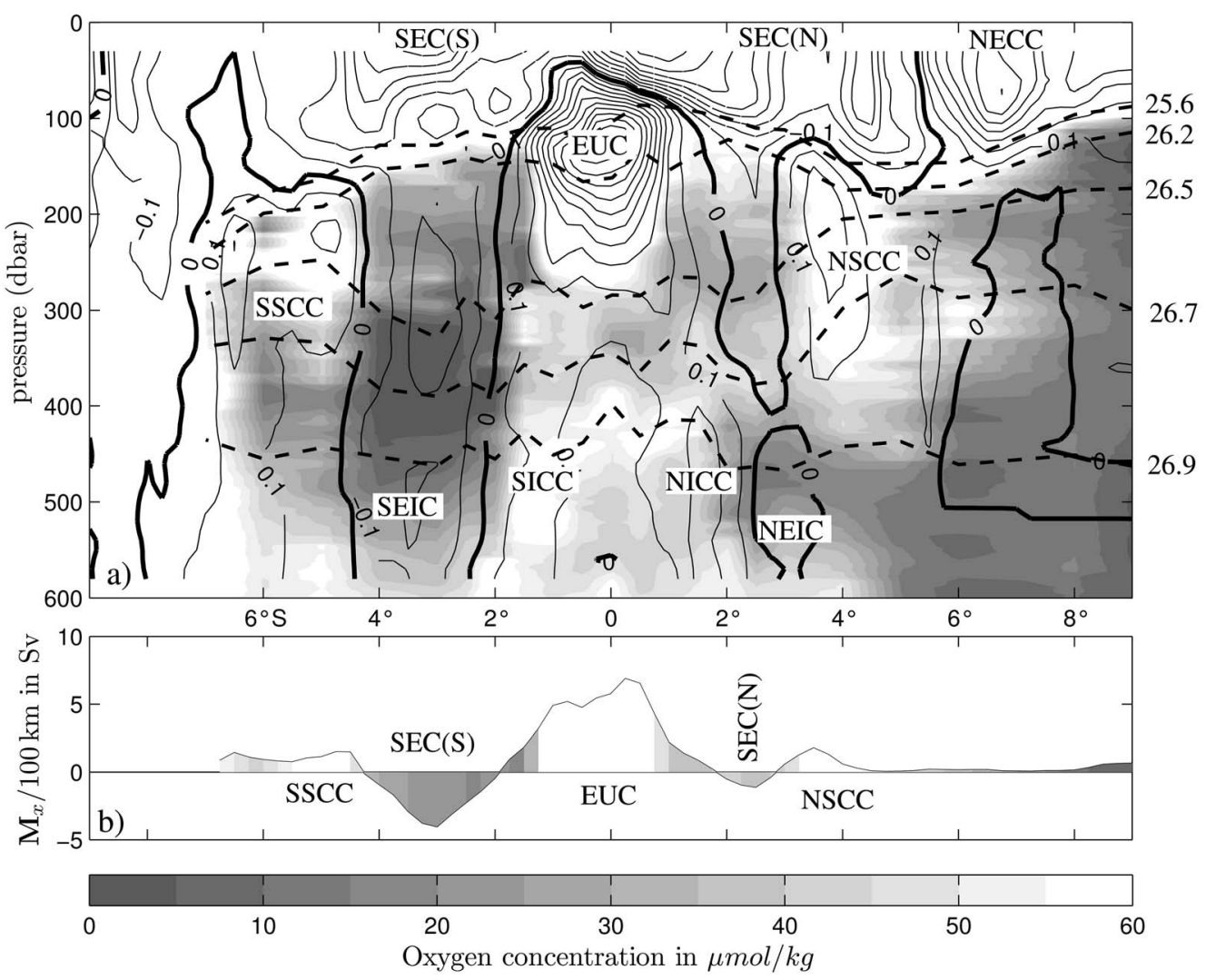

Figure 4. (a) Oxygen distribution (gray shading for 0 to $55 \mu \mathrm{mol} \mathrm{kg}^{-1}$ ), selected isopycnals (dashed lines), and ADCP-measured zonal velocity (black contours at $0.1 \mathrm{~m} \mathrm{~s}^{-1}$ intervals, positive eastward) along $140^{\circ} \mathrm{W}$ in January 2006. Current markings follow Figure 3, adding the northern branch of the South Equatorial Current $(\mathrm{SEC}(\mathrm{N}))$ as well as the South and North Intermediate Countercurrents (SICC and NICC). (b) Transport in Sv $(100 \mathrm{~km})^{-1}$ for $26.2<\sigma_{\theta}<26.5 \mathrm{~kg} \mathrm{~m}^{-3}$, gray shaded by the layer mean oxygen concentration.

Ocean Circulation Experiment (WOCE) and the Tropical Atmosphere-Ocean (TAO) project are used here to study zonal supply paths of oxygen-rich water to the OMZs in the Pacific. The WOCE data include high-quality full-depth vertical profiles of temperature, salinity, and dissolved oxygen versus pressure from a $\mathrm{CTD} / \mathrm{O}_{2}$ (ConductivityTemperature-Depth-Oxygen) instrument calibrated by water sample analyses, upper water column current data from a shipboard ADCP (acoustic Doppler current profiler), and full water column currents from a lowered ADCP in some locations [Firing et al., 1998]. The TAO project has maintained an array of approximately 70 moorings in the equatorial Pacific since the 1990s. Maintenance operations have routinely included meridional sections with $1000 \mathrm{~m} \mathrm{CTD} \mathrm{stations}$ and shipboard ADCP data. On a few of these TAO cruises, dissolved oxygen was measured as well. Data from some of the TAO sections with oxygen measurements and shipboard ADCP measurements will be analyzed here.

[12] The westernmost TAO sections analyzed here, along $170^{\circ} \mathrm{W}$, were occupied by NOAA Ship Ka'imimoana in July 2004 and June 2006. Ka'imimoana sections including oxygen measurements along $140^{\circ} \mathrm{W}$ were occupied in September 2004 and January 2006, and sections along $125^{\circ} \mathrm{W}$ were occupied later during the same cruises in September 2004 and January-February 2006.
[13] We use a TAO section made in June-July 2004 along $155^{\circ} \mathrm{W}$ for oxygen flux computations. TAO sections with oxygen sampling were occupied along $110^{\circ} \mathrm{W}$ in October 2000, November 2003, April 2005 and April 2006. These data contribute to time series constructed here and presented below. In December 2007 and January 2008 ADCP as well as CTD with oxygen samples were collected on a Ronald H. Brown cruise along $110-103^{\circ} \mathrm{W}$ and these data are used here for oxygen flux computations as well as for the time series. In October-November 2003 a TAO section including oxygen sampling along $95^{\circ} \mathrm{W}$ was occupied on the NOAA Ship Ronald H. Brown from $12^{\circ} \mathrm{N}$ to $8^{\circ} \mathrm{S}$, but shipboard ADCP measurements reached only about $350 \mathrm{~m}$. TAO sections along $95^{\circ} \mathrm{W}$ from October 2000, April-May 2005 and April 2006 are also used below as part of an oxygen time series.

[14] A WOCE section, designated P19, was occupied on the $R / V$ Knorr in February-April 1993 with closely spaced full-depth stations across the equator from southern Chile to Guatemala. The section runs along a nominal longitude of $88^{\circ} \mathrm{W}$ in the South Pacific, but shifts to $85^{\circ} \mathrm{W}$ in the equatorial Pacific [Tsuchiya and Talley, 1998]. The shipboard ADCP reached a maximum depth of $493 \mathrm{~m}$. Lowered ADCP data were collected north of $5^{\circ} \mathrm{S}$ and are used here to extend the vertical range of shipboard ADCP data. 


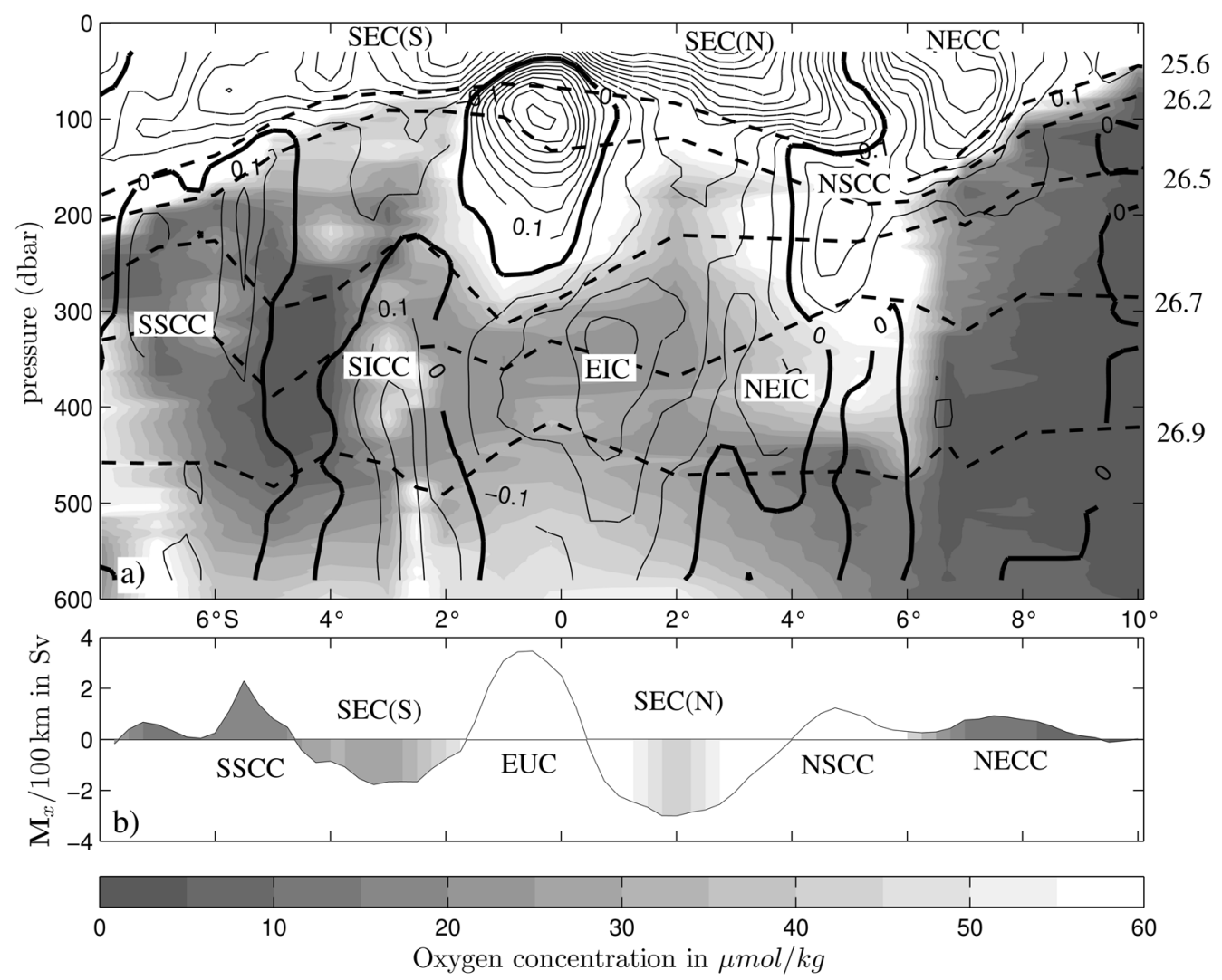

Figure 5. (a) Oxygen distribution (gray shading for $0-55 \mu \mathrm{mol} \mathrm{kg}^{-1}$ ), selected isopycnals (dashed lines), and ADCP-measured zonal velocity (black contours at $0.1 \mathrm{~m} \mathrm{~s}^{-1}$ intervals, positive eastward) along $125^{\circ} \mathrm{W}$ in January-February 2006. Current markings follow Figure 3. (b) Transport in Sv $(100 \mathrm{~km})^{-1}$ for $26.2<$ $\sigma_{\theta}<26.5 \mathrm{~kg} \mathrm{~m}^{-3}$, gray shaded by the layer mean oxygen concentration.

\subsection{Time Series}

[15] Oxygen time series are limited by the sparseness of ocean oxygen measurements. To construct oxygen time series in selected areas we used the HydroBase- 2 programs and data set [Curry, 1996] including the quality-controlled historical hydrographic database WOD05 [Boyer et al., 2006], and supplemented it with more recent data. As older data are sparse and their accuracy more questionable, we start the time series in 1975. To extend the time series toward the present, areas where recent sections with oxygen measurements from the TAO project exist were selected. The areas were centered on the TAO sections to minimize geographical bias. Linear trends were fitted and 95\% confidence intervals computed following Stramma et al. [2008b].

\section{Results}

\subsection{Zonal Currents and the Oxygen Supply in the Tropical Pacific}

[16] There can be no net time-mean advection of oxygen by time mean currents across a time-mean closed surface of a chosen oxygen concentration (oxygen isosurface) bounding the OMZ. However, since no synoptic hydrographic section is likely to follow all, or even much of such a surface (Figure 1), or capture time-mean conditions, there are oxygen transports across the sections analyzed here. Along $170^{\circ} \mathrm{W}$ in July 2004, oxygen concentrations exceed $60 \mu \mathrm{mol} \mathrm{kg}{ }^{-1}$ in the eastward flowing EUC, SSCC, and NSCC (Figure 3). In this section the EUC, SSCC, NSCC, and NECC are all connected (not separated by westward flow). Below $200 \mathrm{~m}$, lower oxygen values are associated with the westward flow of the EIC and with bands of westward flow at $3-5^{\circ} \mathrm{S}$ and 4- $6^{\circ} \mathrm{N}$. At this longitude $\sigma_{\theta}=26.2$ and $26.5 \mathrm{~kg} \mathrm{~m}^{-3}$, which roughly bound the SCC cores in the eastern Pacific, are separated by less than $50 \mathrm{~m}$, except for a spreading to $80 \mathrm{~m}$ in the lower part of the EUC and the upper EIC. The major zonal transports for $26.2<\sigma_{\theta}<26.5 \mathrm{~kg} \mathrm{~m}^{-3}$ are found within the secondary SSCC, the southern part of the EUC, and the NSCC (Figure 3b). The velocity cores of the two SCCs are denser than $\sigma_{\theta}=26.5 \mathrm{~kg} \mathrm{~m}^{-3}$ in the central Pacific, and the SSCC carries oxygen-rich water eastward, as does the EUC in the upper ocean. The NSCC caries oxygenrich water in its upper layer, but below $300 \mathrm{~m}$ the NSCC is partly influenced by an admixture of oxygen-poor water (likely from the north, given its low salinity signature).

[17] Farther east, along $140^{\circ} \mathrm{W}$ in January 2006, the eastward flowing EUC, SSCC, and NSCC are separated by strong westward flowing branches of the SEC (Figure 4). The thickness of $26.2<\sigma_{\theta}<26.5 \mathrm{~kg} \mathrm{~m}^{-3}$ increases to more than $150 \mathrm{~m}$, especially between $4^{\circ} \mathrm{S}$ and $3^{\circ} \mathrm{N}$. Dissolved oxygen content along $140^{\circ} \mathrm{W}$ is lower compared to $155^{\circ} \mathrm{W}$ (the gray shading scale is identical for Figures $4-7$, but different for Figure 3), with much lower oxygen in the westward flow between 2 and $4^{\circ} \mathrm{S}$ and north of $6^{\circ} \mathrm{N}$. The 


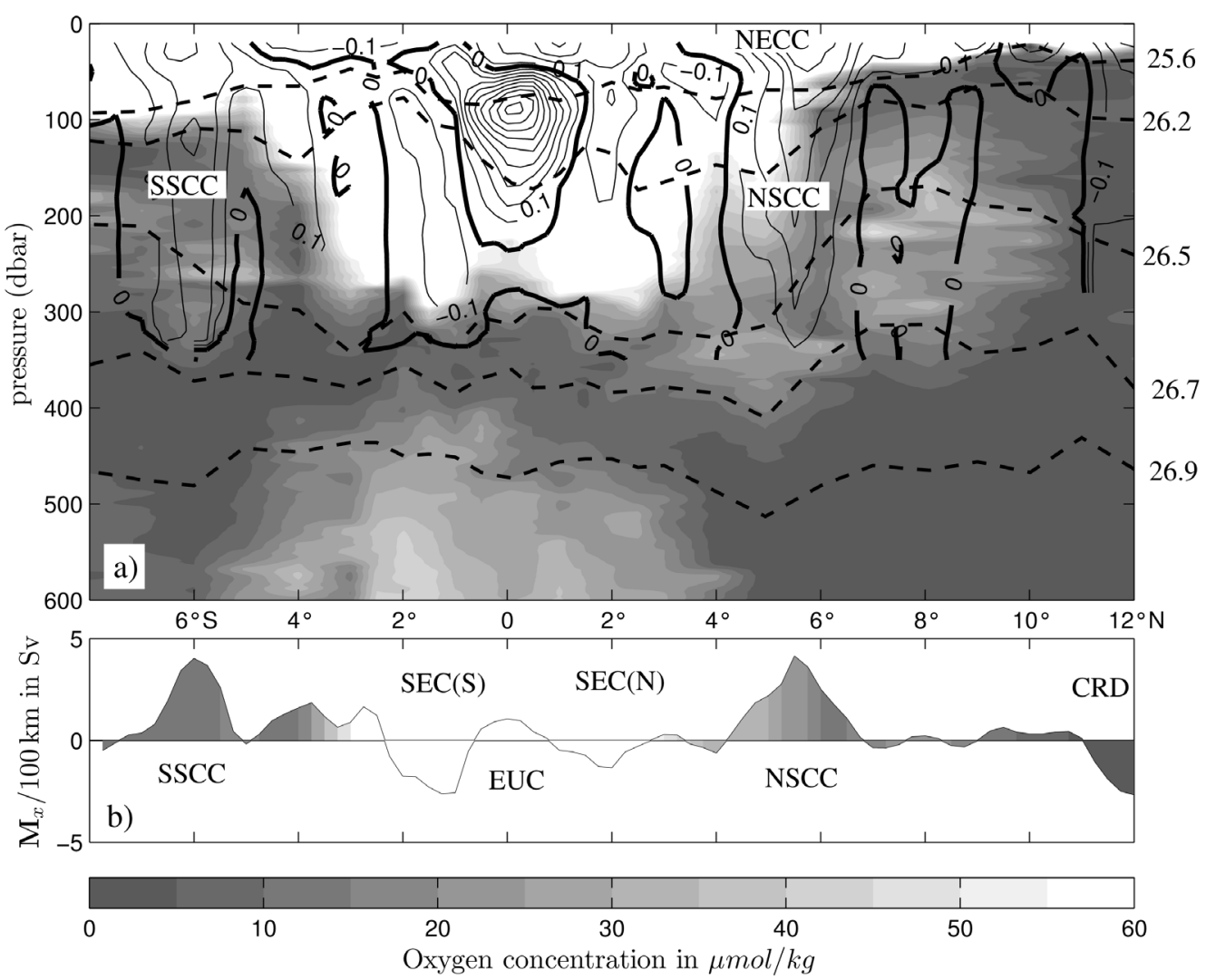

Figure 6. (a) Oxygen distribution (gray shading for $0-55 \mu \mathrm{mol} \mathrm{kg}^{-1}$ ), selected isopycnals (dashed lines), and ADCP-measured zonal velocity (black contours at $0.1 \mathrm{~m} \mathrm{~s}^{-1}$ intervals, positive eastward) along $\sim 95^{\circ} \mathrm{W}$ in October-November 2003. Current markings follow Figure 3, adding the Costa Rica Dome (CRD). (b) Transport in Sv $(100 \mathrm{~km})^{-1}$ for $26.2<\sigma_{\theta}<26.5 \mathrm{~kg} \mathrm{~m}^{-3}$, gray shaded by the layer mean oxygen concentration.

SCCs still have higher oxygen concentrations in their cores, but some admixture of oxygen-poor water from the neighboring westward flow is obvious below the current cores. The current cores at $140^{\circ} \mathrm{W}$ are located within $26.2<\sigma_{\theta}<$ $26.5 \mathrm{~kg} \mathrm{~m}^{-3}$, contrasting with $170^{\circ} \mathrm{W}$. The NICC and especially the SICC carry relatively oxygen-rich water eastward at 400 to $600 \mathrm{~m}$.

[18] Along $125^{\circ} \mathrm{W}$ in January-February 2006 (Figure 5), the NSCC is strong, as is the NECC, to which it is connected. The NSCC core also carries relatively oxygen-rich water. South of the equator, the SSCC is strongly influenced by the surrounding oxygen-poor water. While the NICC is weak in this section, the SICC is well developed, carries relatively oxygen-rich water eastward, and hence is a deep provider of oxygen-rich water to the OMZ. The EIC is well developed in this section, centered at about $350 \mathrm{~m}$, and carries oxygenpoor water westward. In contrast, in the nearly contemporaneous $140^{\circ} \mathrm{W}$ section, the EIC is absent. The large changes in strength or even absence of the deeper currents like the EIC, SICC, and NICC from section to section shows that the variability of these currents is near their mean magnitude.

[19] Along $95^{\circ} \mathrm{W}$ in November 2003 (Figure 6), the shipboard ADCP only measured currents in the upper $350 \mathrm{~m}$. The well oxygenated surface layer is separated from the oxygenpoor layers of the OMZ below near $\sigma_{\theta}=25.6 \mathrm{~kg} \mathrm{~m}^{-3}$. The EUC transports relatively oxygen-rich water eastward
(Figure 6b). The SEC branches found poleward of the EUC in both hemispheres recirculate this relatively oxygen-rich water from the EUC westward. The SSCC at about $6^{\circ} \mathrm{S}$ is located in the OMZ, but its core at 250 to 350 dbar carries slightly oxygen-rich (but much poorer than the EUC and SEC(S)) waters eastward at 250 to $300 \mathrm{~m}$. The NSCC at $6^{\circ} \mathrm{N}$ separates the oxygen-richer water of the equatorial region from the oxygen-poor water to the north. The two small westward current bands at 7 and $8^{\circ} \mathrm{N}$ just below the NECC carry oxygen-rich water, and hence might be transient recirculations of oxygen-enhanced equatorial water masses. In the north a thick layer of oxygen-poor water is found under the Costa Rica Dome. Near the equator the oxygenpoor layer covers only the depth range 300 to $500 \mathrm{~m}$. At 500 to $800 \mathrm{~m}$ the oxygen content rises, apparently connected to the eastward flow near the equator and presumably the SICC and NICC measured at about $2^{\circ} \mathrm{S}$ and $3^{\circ} \mathrm{N}$.

[20] The OMZs of the eastern South and North Pacific along $85^{\circ} \mathrm{W}$ were entirely sampled in March and April 1993 (Figure 7). The southern limit of the South Pacific OMZ is near $18^{\circ} \mathrm{S}$. The South Equatorial Current (SEC) and the Humboldt Current between 15 and $10^{\circ} \mathrm{S}$ carry oxygen-poor water from the OMZ westward. The SCCs also carry relatively oxygen-poor water eastward, leaving the deep EUC as a major source of subthermocline oxygen-rich water at this longitude. Higher oxygen values are found in the SICC and 


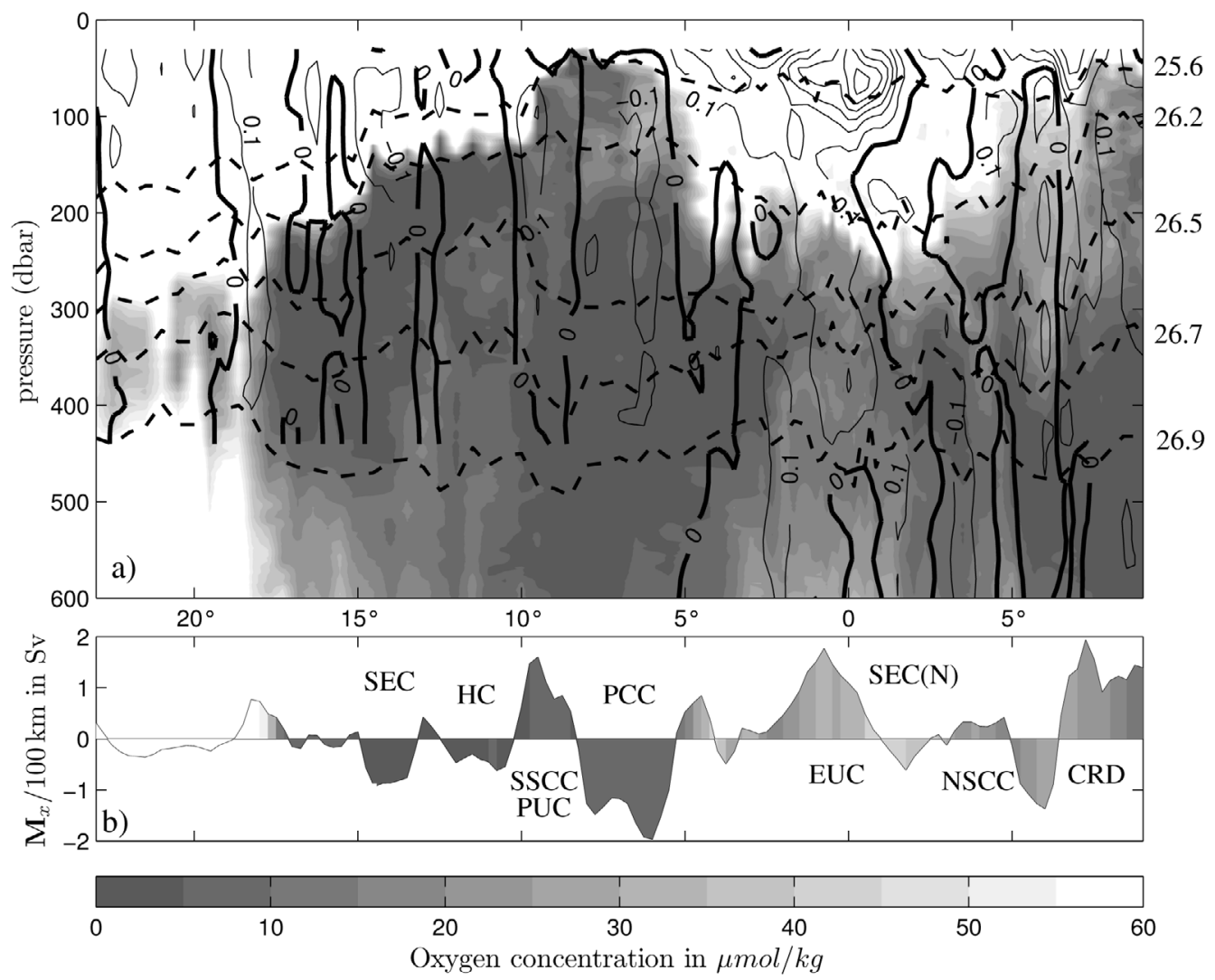

Figure 7. (a) Oxygen distribution (gray shading for $0-55 \mu \mathrm{mol} \mathrm{kg}^{-1}$ ), selected isopycnals (dashed lines), and ADCP-measured zonal velocity (black contours at $0.1 \mathrm{~m} \mathrm{~s}^{-1}$ intervals, positive eastward) along $\sim 85^{\circ} \mathrm{W}$ in March-April 1993. North of $5^{\circ} \mathrm{S}$ currents below 450 dbar are from the lowered ADCP. Current markings follow Figure 3, adding the Humboldt Current (HC), the Peru-Chile Undercurrent (PUC) as a continuation of the SSCC, the Peru-Chile Current (PCC), and the Costa Rica Dome (CRD). (b) Transport in Sv $(100 \mathrm{~km})^{-1}$ for $26.2<\sigma_{\theta}<26.5 \mathrm{~kg} \mathrm{~m}^{-3}$, gray shaded by the layer mean oxygen concentration.

NICC at about $2^{\circ} \mathrm{S}$ and $2^{\circ} \mathrm{N}$ near $500 \mathrm{~m}$. (The eastward flow on the equator from 200 to $400 \mathrm{~m}$ also has slightly elevated oxygen, but is mostly too dense to be considered part of the EUC.) North of $5^{\circ} \mathrm{N}$ very oxygen-poor waters span a wide depth range centered near $500 \mathrm{~m}$, and the eastward component of the Costa Rica Dome (CRD) carries oxygenpoor water northeastward.

[21] The mass transports and oxygen fluxes of the eastward near-equatorial currents are highly variable from one synoptic section to the next (Tables $1 \mathrm{a} 1 \mathrm{~b} 1 \mathrm{c}$ ); the variability is of the same magnitude as the mean currents. Hence it is difficult to discern a clear zonal trend in either variable. Nonetheless, there is a suggestion of a decrease to the east, particularly in the eastern part of the domain. Dividing the mass transport by oxygen flux yields a transport-weighted oxygen concentration, and this quantity does decrease systematically from west to east, as expected from the climatological oxygen distribution.

[22] Oxygen concentrations of the net eastward and westward flows in the tropical Pacific between $8^{\circ} \mathrm{S}$ and $8^{\circ} \mathrm{N}$ for selected density layers (Figure 8) reveal several patterns despite the strong variability in the synoptic meridional crossequatorial sections analyzed here. Again as expected, these velocity-weighted oxygen concentrations generally decrease from west to east in all layers. Except at $95^{\circ} \mathrm{W}$, as discussed below, velocity weighted oxygen concentrations for the eastward flow are higher (by 2 to $51 \mu \mathrm{mol} \mathrm{kg}^{-1}$ ) than those for westward currents in all the density layers. Hence the eastward flows supply oxygen-richer waters to the OMZs while the westward flows remove oxygen-poorer water. The concentration differences between eastward and westward flow generally decrease in magnitude with increasing density. While some of the lightest layer is within the thermocline, and may intersect with only the top of the OMZ, the second lightest layer, which captures some of the SCCs, certainly

Table 1a. Eastward Mass Transports, Oxygen Fluxes, and Oxygen Concentration in the EUC for $26.2<\sigma_{\theta}<26.5 \mathrm{~kg} \mathrm{~m}^{-3}$ between $2^{\circ} \mathrm{S}$ and $2^{\circ} \mathrm{N}^{\mathrm{a}}$

\begin{tabular}{lccc}
\hline Section/Time (mm/yy) & EUC-Transport & EUC-Flux & Flux/Transport \\
\hline $170^{\circ} \mathrm{W} \mathrm{07/04}$ & 1.9 & 238.7 & 125 \\
$155^{\circ} \mathrm{W} \mathrm{06-07/04}$ & 5.3 & 615.8 & 116 \\
$140^{\circ} \mathrm{W} \mathrm{01/06}$ & 15.6 & 1263.8 & 81 \\
$125^{\circ} \mathrm{W} \mathrm{01-02/06}$ & 6.5 & 634.0 & 97 \\
$110^{\circ} \mathrm{W} \mathrm{12/07-01/08}$ & 21.1 & 1287.4 & 61 \\
$95^{\circ} \mathrm{W} \mathrm{10-11/03}$ & 1.4 & 136.3 & 97 \\
$85^{\circ} \mathrm{W} 03-04 / 93$ & 3.4 & 97.0 & 29 \\
\hline
\end{tabular}

${ }^{\mathrm{a}}$ Mass transports, transport in $10^{9} \mathrm{~kg} \mathrm{~s}^{-1}$; oxygen fluxes, $10^{3} \mathrm{~mol} \mathrm{~s}^{-1}$; oxygen concentration (oxygen flux divided by mass transport), flux/

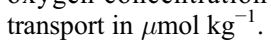


Table 1b. Eastward Mass Transports, Oxygen Fluxes, and Oxygen Concentration in the SSCC and the NSCC for $\sigma_{\theta}=26.2<\sigma_{\theta}<$ $26.9 \mathrm{~kg} \mathrm{~m}^{-3 \mathrm{a}}$

\begin{tabular}{lcccccccc}
\hline Section/Time (mm/yy) & SSCC Area & Transport & Flux & Flux/Transport & NSCC Area & Transport & Flux & Flux/Transport \\
\hline $170^{\circ} \mathrm{W} \mathrm{07/04}$ & $8^{\circ} \mathrm{S}-2^{\circ} \mathrm{S}$ & 9.6 & 951.4 & 99 & $2^{\circ} \mathrm{N}-5^{\circ} \mathrm{N}$ & 8.9 & 792.6 & 89 \\
$155^{\circ} \mathrm{W} \mathrm{06-07/04}$ & $8^{\circ} \mathrm{S}-3^{\circ} \mathrm{S}$ & 3.1 & 261.0 & 84 & $2^{\circ} \mathrm{N}-6^{\circ} \mathrm{N}$ & 3.8 & 316.9 & 83 \\
$140^{\circ} \mathrm{W} \mathrm{01/06}$ & $8^{\circ} \mathrm{S}-4^{\circ} \mathrm{S}$ & 9.1 & 434.3 & 48 & $3^{\circ} \mathrm{N}-7^{\circ} \mathrm{N}$ & 8.9 & 496.5 & 56 \\
$125^{\circ} \mathrm{W} \mathrm{01-02/06}$ & $8^{\circ} \mathrm{S}-4^{\circ} \mathrm{S}$ & 7.8 & 138.8 & 18 & $3^{\circ} \mathrm{N}-7^{\circ} \mathrm{N}$ & 6.7 & 377.2 & 56 \\
$110^{\circ} \mathrm{W} \mathrm{12/07-01/08}$ & $8^{\circ} \mathrm{S}-3^{\circ} \mathrm{S}$ & 9.0 & 206.9 & 23 & $3^{\circ} \mathrm{N}-8^{\circ} \mathrm{N}$ & 12.7 & 390.5 & 31 \\
$85^{\circ} \mathrm{W} \mathrm{03-04/93}$ & $11^{\circ} \mathrm{S}-7^{\circ} \mathrm{S}^{\mathrm{b}}$ & 3.0 & 17.1 & 6 & $2^{\circ} \mathrm{N}-6^{\circ} \mathrm{N}$ & 0.8 & 18.6 & 23 \\
\hline
\end{tabular}

${ }^{\mathrm{a}}$ Mass transports, transport in $10^{9} \mathrm{~kg} \mathrm{~s}^{-1}$; oxygen fluxes, $10^{3} \mathrm{~mol} \mathrm{~s}^{-1}$; oxygen concentration (oxygen flux divided by mass transport), flux/transport in $\mu \mathrm{mol} \mathrm{kg}^{-1}$.

${ }^{\mathrm{b}}$ Shallow ADCP; lower boundary at $\sigma_{\theta}=26.8 \mathrm{~kg} \mathrm{~m}^{-3}$.

feeds the OMZ, as do the two densest layers. The largest differences in velocity-weighted oxygen concentrations for eastward and westward flow are found at $140^{\circ} \mathrm{W}$, near the edge of the OMZs, and they generally decrease from there eastward. In the anomalous $95^{\circ} \mathrm{W}$ section westward flow is weak and concentrated on the SEC with relatively high oxygen (Figure 6), perhaps derived from the relatively oxygen-rich EUC, while the eastward flow shows lower oxygen concentration (Figure 8) owing to low oxygen concentrations in the SSCC and NSCC (see Figure 6).

\subsection{Oxygen Time Series}

[23] To begin to address the difficult question of multidecadal temporal variability of oxygen concentration near the equator, recent TAO section data are combined with historical data. Since the tropical Pacific OMZs do not exhibit strong seasonality [Paulmier and Ruiz-Pino, 2009], oxygen data are used here regardless of the season in which they are collected.

[24] Annual mean 200 to $700 \mathrm{~m}$ dissolved oxygen time series since 1975 are constructed for regions from $3^{\circ} \mathrm{S}$ to $3^{\circ} \mathrm{N}$ centered on four TAO longitudes. A depth layer is chosen, rather than a density layer, to include any vertical expansion or other shifts of the OMZ. These regions cover the area of the major oxygen supply path for the eastern tropical Pacific OMZs. All four selected areas show decreasing oxygen (Figure 9) over the last 30 years. Linear fits estimate trends of oxygen concentrations from -0.55 to $-0.32 \mu \mathrm{mol} \mathrm{kg}^{-1} \mathrm{yr}^{-1}$. Trends at $165-175^{\circ} \mathrm{W}, 105-115^{\circ} \mathrm{W}$, and $90-100^{\circ} \mathrm{W}$ are significantly different from zero at $95 \%$ confidence (Table 2). Time series for larger geographical regions containing areas in Figures 9a and 9c [Stramma et al., 2008b] are noisier than those presented here, perhaps because they include data from larger areas, resulting in aliased sampling of spatial variability (Figure 2).

[25] Temporal trends of dissolved oxygen time series for the density layer $26.2<\sigma_{\theta}<27.18 \mathrm{~kg} \mathrm{~m}^{-3}$ are similar to those for the 200-700 m layer (Table 2). This density layer approximately spans 200 to $700 \mathrm{~m}$ in the equatorial Pacific (Table 2), but because isopycnals are not level, the correspondence cannot be exact. For example, the mean density layer oxygen values are slightly lower than those for the depth layer at $165^{\circ} \mathrm{W}-175^{\circ} \mathrm{W}$ (Figure 9a), because on the western side of our investigation area $\sigma_{\theta}=26.2 \mathrm{~kg} \mathrm{~m}^{-3}$ is located at about $250 \mathrm{~m}$ depth, so here the density layer chosen excludes some the relative high oxygen values between 200 and around $250 \mathrm{~m}$. There are no obvious temporal trends of bounding isopycnal depths in any of the study areas. The similarity between the oxygen trends for these depth and density layers reinforces the hypothesis of a loss of oxygen from the tropical thermocline.

[26] Variability on shorter timescales or larger spatial scales may influence or alias the linear trends computed here. The data do not resolve shorter timescales well. Nonetheless, in three out of four areas studied linear trends for the depth layer are statistically different from zero at $95 \%$ confidence. Linear trends and their 95\% confidence intervals were estimated using least squares procedures [e.g., Wunsch, 1996], and these trends account for 26 to $54 \%$ of the total variance (Table 2). Degrees of freedom used to compute the confidence intervals were estimated using integral timescales [e.g., von Storch and Zwiers, 1999]. One of the longest time series of oxygen, although far from the OMZ, has been maintained at Ocean Station Papa in the North Pacific at $50^{\circ} \mathrm{N}$. This 50 year time series shows the influence of both short-term (few year to bidecadal) atmospheric or oceanic circulation oscillations and a persistent multidecadal climate trend [Whitney et al., 2007]. El Niños might influence oxygen concentrations in the tropical Pacific. During El Niño, equatorial Kelvin waves transit the eastern equatorial Pacific, deepening the thermocline, which in turn, potentially deepens and partially erodes the oxycline [Fuenzalida et al., 2009]. After 1975, strong El Niños occurred in 1982-83, 1991-92 and 1997-98. Within the limits of the sampling, there are no clear oxygen decreases associated with these years in the time series. These considerations notwithstanding, there

Table 1c. Eastward Mass Transports, Oxygen Fluxes, and Oxygen Concentration in the SICC and NICC from $\sigma_{\theta}=26.7 \mathrm{~kg} \mathrm{~m}^{-3}$ to $600 \mathrm{dbar}^{\mathrm{a}}$

\begin{tabular}{lcccccccc}
\hline Section/Time $(\mathrm{mm} / \mathrm{yy})$ & SICC Area & Transport & Flux & Flux/Transport & NICC Area & Transport & Flux & Flux/Transport \\
\hline $155^{\circ} \mathrm{W} \mathrm{06-07/04}$ & $3^{\circ} \mathrm{S}-0^{\circ} \mathrm{S}$ & 3.6 & 234.3 & 65 & $1^{\circ} \mathrm{N}-3^{\circ} \mathrm{N}$ & 0.6 & 38.6 & 64 \\
$140^{\circ} \mathrm{W} \mathrm{01/06}$ & $3^{\circ} \mathrm{S}-0^{\circ} \mathrm{S}$ & 5.0 & 250.2 & 50 & $0^{\circ} \mathrm{N}-3^{\circ} \mathrm{N}$ & 8.1 & 349.4 & 43 \\
$125^{\circ} \mathrm{W} \mathrm{01-02/06}$ & $4^{\circ} \mathrm{S}-1^{\circ} \mathrm{S}$ & 6.7 & 234.9 & 35 & $2^{\circ} \mathrm{N}-5^{\circ} \mathrm{N}$ & 1.4 & 37.9 & 27 \\
$110^{\circ} \mathrm{W} \mathrm{12/07-01/08}$ & $3^{\circ} \mathrm{S}-0^{\circ} \mathrm{S}$ & 11.2 & 388.7 & 35 & $0^{\circ} \mathrm{N}-4^{\circ} \mathrm{N}$ & 17.1 & 458.1 & 27 \\
$85^{\circ} \mathrm{W} \mathrm{03-04/93}$ & $5^{\circ} \mathrm{S}-0^{\circ} \mathrm{S}$ & 8.7 & 115.1 & 13 & $0^{\circ} \mathrm{N}-4^{\circ} \mathrm{N}$ & 4.3 & 53.9 & 13 \\
\hline
\end{tabular}

${ }^{a}$ Mass transports, transport in $10^{9} \mathrm{~kg} \mathrm{~s}^{-1}$; oxygen fluxes, $10^{3} \mathrm{~mol} \mathrm{~s}^{-1}$; oxygen concentration (oxygen flux divided by mass transport), flux/transport in $\mu \mathrm{mol} \mathrm{kg}{ }^{-1}$. 


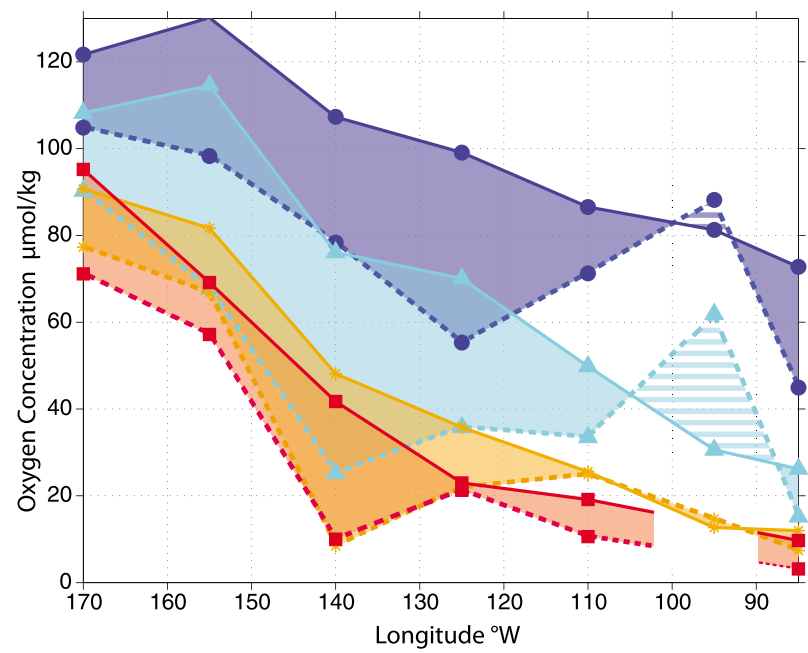

Figure 8. Eastward (solid lines) and westward (dashed lines) oxygen concentration (oxygen flux divided by mass transport, in $\mu \mathrm{mol} \mathrm{kg}{ }^{-1}$ ) versus longitude for selected density layers between $8^{\circ} \mathrm{S}$ and $8^{\circ} \mathrm{N}$, except $170^{\circ} \mathrm{W}, 8^{\circ} \mathrm{S}-6^{\circ} \mathrm{N}$ and $140^{\circ} \mathrm{W}, 7^{\circ} \mathrm{S}-8^{\circ} \mathrm{N}$ for $25.6<\sigma_{\theta}<26.2 \mathrm{~kg} \mathrm{~m}^{-3}$ (blue shading and circles); $26.2<\sigma_{\theta}<26.5 \mathrm{~kg} \mathrm{~m}^{-3}$ (cyan shading and triangles); $26.5<\sigma_{\theta}<26.7 \mathrm{~kg} \mathrm{~m}^{-3}$ (orange shading and stars); and $26.7<\sigma_{\theta}<26.9 \mathrm{~kg} \mathrm{~m}^{-3}$ (red shading and squares). Values at $95^{\circ} \mathrm{W}$ for $26.5<\sigma_{\theta}<26.7 \mathrm{~kg} \mathrm{~m}^{-3}$ and at $85^{\circ} \mathrm{W}$ for $26.7<$ $\sigma_{\theta}<26.9 \mathrm{~kg} \mathrm{~m}^{-3}$ are incomplete as the ADCP did not sample the deepest portions of these layers over the entire section. does appear to be evidence for a reduction of oxygen values in the zonal equatorial oxygen supply path for the Pacific OMZs.

\section{Discussion and Summary}

[27] In the tropical Pacific all westward currents remove oxygen-poor water from the OMZs while the eastward zonal currents with a subthermocline expression supply oxygenricher water to the OMZs, including (from shallow to deep), the EUC, the SCCs, and the ICCs (Tables 1a-1c). At the core layer of the SCCs $\left(26.2<\sigma_{\theta}<26.5 \mathrm{~kg} \mathrm{~m}^{-3}\right)$ the lower reaches of the EUC and the SCCs/NECC carry oxygen-rich $13 \mathrm{CW}$ eastward (Figure 2a). Despite their large variability the NICC and SICC (Figure 2b) are major supply paths at intermediate depth in the Pacific carrying oxygen-rich AAIW eastward. While the ICCs have lower oxygen fluxes than the SCCs, they have higher oxygen values in the Eastern Pacific. In the far eastern $\left(85^{\circ} \mathrm{W}\right)$ tropical Pacific, well within the OMZs, the SCCs carry relatively oxygen-poor water.

[28] These findings contrast with the eastern North Atlantic where the NEUC/NECC is a strong oxygen contributor to the OMZs even in the eastern reaches of the Atlantic [Stramma et al., 2008a]. Although the North Pacific OMZ is stronger than the South Pacific OMZ, the NSCC carries a higher oxygen load than the SSCC. This difference may be related to the higher volume transports in the NSCC compared to the SSCC [Rowe et al., 2000]. The eastward decrease in oxygen is well represented in the oxygen fluxes of the EUC, the $\mathrm{SCCs}$, and the ICCs. One reason for the weak oxygen values in the SCCs in the far eastern Pacific may be that the SCCs

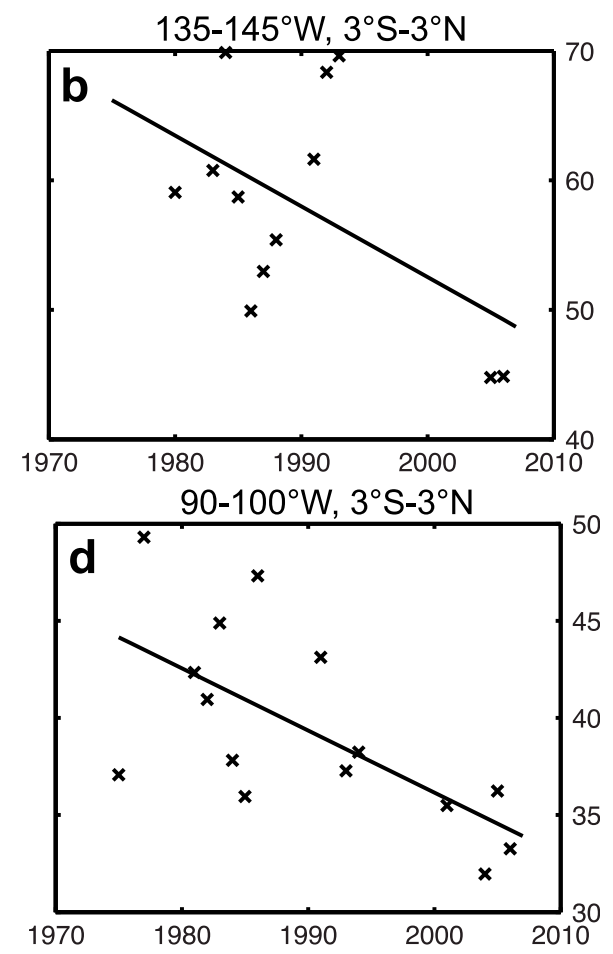

Figure 9. Time series of annual mean 200-700 m dissolved oxygen concentrations (black "x"s) since 1975 (in $\mu \mathrm{mol} \mathrm{kg}{ }^{-1}$ ) with linear fits (solid lines). Trend values and their $95 \%$ confidence intervals from the fits are given in Table 2 . Areas analyzed are between $3^{\circ} \mathrm{S}$ and $3^{\circ} \mathrm{N}$ at (a) $165^{\circ} \mathrm{W}-175^{\circ} \mathrm{W}$, (b) $135^{\circ} \mathrm{W}-$ $145^{\circ} \mathrm{W}$, (c) $105^{\circ} \mathrm{W}-115^{\circ} \mathrm{W}$, and (d) $90^{\circ} \mathrm{W}-100^{\circ} \mathrm{W}$. In Figure $9 \mathrm{a}$ the time series for the isopycnal layer $\sigma_{\theta}=26.2-27.18 \mathrm{~kg} \mathrm{~m}^{-3}$ is included (red plus signs) with a linear fit (dashed line). 
Table 2. Temporal Oxygen Trends and Their 95\% Confidence Intervals From Linear Fits for a 200-700 m Layer and an Isopycnal Layer $^{\mathrm{a}}$

\begin{tabular}{ccccccccc}
\hline & \multicolumn{3}{c}{$200-700 \mathrm{~m}$ Layer } & & \multicolumn{3}{c}{ Isopycnal Layer } \\
\cline { 2 - 3 } Area & Trend Confidence & Variance $(\%)$ & Degrees of Freedom & & Trend Confidence & Variance (\%) & Degrees of Freedom \\
\hline $3^{\circ} \mathrm{S}-3^{\circ} \mathrm{N}, 165^{\circ} \mathrm{W}-175^{\circ} \mathrm{W}$ & $-0.38 \pm 0.30$ & 43 & 12.0 & & $-0.40 \pm 0.26$ & 43 & 11.0 \\
$3^{\circ} \mathrm{S}-3^{\circ} \mathrm{N}, 135^{\circ} \mathrm{W}-145^{\circ} \mathrm{W}$ & $-0.55 \pm 0.88$ & 26 & 7.1 & & $-0.46 \pm 0.79$ & 20 & 7.8 \\
$3^{\circ} \mathrm{S}-3^{\circ} \mathrm{N}, 105^{\circ} \mathrm{W}-115^{\circ} \mathrm{W}$ & $-0.49 \pm 0.24$ & 54 & 15.7 & & $-0.52 \pm 0.31$ & 56 & 11.6 \\
$3^{\circ} \mathrm{S}-3^{\circ} \mathrm{N}, 90^{\circ} \mathrm{W}-100^{\circ} \mathrm{W}$ & $-0.32 \pm 0.22$ & 42 & 13.0 & & $-0.21 \pm 0.28$ & 22 & 9.5 \\
\hline
\end{tabular}

${ }^{\mathrm{a}}$ Temporal oxygen trends are reported in $\mu \mathrm{mol} \mathrm{kg}^{-1} \mathrm{yr}^{-1}$. Isopycnal layer is $26.2<\sigma_{\theta}<27.18 \mathrm{~kg} \mathrm{~m}^{-3}$ and roughly spans the $200-700 \mathrm{~m}$ depth range. Percentages of the total variance are accounted for by the linear trends, and the degrees of freedom used in the uncertainty estimates are also reported.

${ }^{\mathrm{b}}$ See Figure 9.

rise in depth and decrease in density from west to east, so only a fraction of the water in the eastern SCCs can have arrived directly following isopycnals from the west; meridional and diapycnal exchanges must be involved [Rowe et al., 2000].

[29] In a steady state ocean, the oxygen distribution at any given point is determined through an equilibrium between oxygen flux divergences and consumption (respiration) through biogeochemical processes [e.g., Wyrtki, 1962]. At higher latitudes most of the oxygen loss may be biologically mediated through links between heating and stratification [Keeling and Garcia, 2002]. However, the geographical location of the tropical Pacific OMZ appears to be determined to first order by patterns of upwelling, regions of general sluggish horizontal transport at the eastern boundaries, and to a lesser extent by regions with high productivity as indicated through ocean color data [Karstensen et al., 2008]. With our relatively sparse data set it is not possible to determine whether biological or circulation changes cause the oxygen decrease in the equatorial area in the face of highly variable currents.

[30] While a complete or quantitative oxygen budget of the OMZs is beyond the scope of this investigation, it is interesting to put the synoptic oxygen fluxes for the EUC, the SCCs, and the ICCs presented here into a qualitative context by estimating the diffusive oxygen fluxes into the OMZs for comparison, and by assessing the bulk oxygen consumption rate implied by summing the (admittedly rough and incomplete) advective and diffusive fluxes. The mass transport estimated for the EUC, the SCCs and the ICCs (Tables 1a-1c) at and west of $125^{\circ} \mathrm{W}$ is about $30 \times 10^{9} \mathrm{~kg} \mathrm{~s}^{-1}$. If we assume that the mass flux of these eastward currents is returned by the adjacent westward currents, and that the typical oxygen concentration difference between eastward and westward flows is about $20 \mu \mathrm{mol} \mathrm{kg}^{-1}$ (Figure 8), we get a net oxygen flux of $0.6 \times 10^{6} \mathrm{~mol} \mathrm{~s}^{-1}$.

[31] We make rough estimates of the diffusive fluxes through the climatological $60 \mu \mathrm{mol} \mathrm{kg}{ }^{-1}$ surface surrounding the tropical Pacific OMZ. We first compute the gradients perpendicular to this surface, then apply a representative diapycnal diffusion coefficient of $1 \times 10^{-5} \mathrm{~m}^{2} \mathrm{~s}^{-1}$ [Ledwell et al., 1998] to their vertical component, and a representative isopycnal diffusion coefficient of $500 \mathrm{~m}^{2} \mathrm{~s}^{-1}$ [Davis, 2005] to their lateral component. While Davis [2005] found a much larger value for the zonal component of lateral diffusivity near the equator, we use $500 \mathrm{~m}^{2} \mathrm{~s}^{-1}$, more characteristic of off-equatorial regions in his analysis, since using that larger equatorial value would arguably double count much of the fluxes estimated from synoptic zonal currents above. Integrating these products over the surface area results in a vertical oxygen flux of $0.4 \times 10^{6} \mathrm{~mol} \mathrm{~s}^{-1}$, mostly through the top surface where the vertical gradients are large. The lateral diffusive flux, similarly estimated, is $0.8 \times 10^{6} \mathrm{~mol} \mathrm{~s}^{-1}$, somewhat larger than either the zonal advective flux or the vertical diffusive flux.

[32] The mass of the tropical Pacific OMZs (water between $30^{\circ} \mathrm{S}$ and $30^{\circ} \mathrm{N}$ with oxygen concentrations $\left.<60 \mu \mathrm{mol} \mathrm{kg}{ }^{-1}\right)$ is about $16 \times 10^{18} \mathrm{~kg}$. Dividing the sum of the flux estimates made above by the OMZ mass gives an oxygen utilization rate (OUR) of about $4 \mu \mathrm{mol} \mathrm{kg} \mathrm{mr}^{-1}$. We are aware of no other OUR estimates specific to the OMZ, but this result compares favorably to 6.6 to $3.2 \mu \mathrm{mol} \mathrm{kg}^{-1} \mathrm{yr}^{-1}$, the range corresponding to $25.5<\sigma_{\theta}<26.6 \mathrm{~kg} \mathrm{~m}^{-3}$ inferred for the subtropical North Pacific [Sonnerup et al., 1999]. This exercise suggests zonal current oxygen fluxes as estimated here may make a significant contribution to the $\mathrm{OMZ}$ oxygen budget, along with vertical and lateral diffusive fluxes. Hence changes of these zonal fluxes could contribute to OMZ temporal and spatial variations.

[33] Multidecadal oxygen time series are difficult to construct from the few observations available. However, by combining historical equatorial oxygen measurements with recent TAO measurements, we find oxygen decreasing by roughly $0.5 \mu \mathrm{mol} \mathrm{kg}^{-1} \mathrm{yr}^{-1}$ over the last 30 years, averaged within 3 degrees of the Equator and east of the Dateline, and from 200 to $700 \mathrm{~m}$ as well as for a corresponding density layer. The scatter is very large, however, and it remains to be seen whether the signal is decadal variability such as the slowdown and recent rebound of the subtropical cell in the upper Pacific Ocean [McPhaden and Zhang, 2004], or a longer-term climate change.

[34] Acknowledgments. We thank Julia Hummon for processing the shipboard ADCP data and Kristene McTaggart for processing the TAO $\mathrm{CTD} / \mathrm{O}_{2}$ data. Financial support was received through the IFM-GEOMAR (L.S and S.S.), the NOAA Office of Oceanic and Atmospheric Research (G.C.J. and S.S.), and National Science Foundation grant OCE03-27334 (E.F.). This work is a contribution of Sonderforschungsbereich 754 "Climate-Biogeochemistry interactions in the tropical ocean" (www. sfb754.de), which is supported by the Deutsche Forschungsgemeinschaft. Findings and conclusions in this article are those of the authors and do not necessarily represent the views of the National Oceanic and Atmospheric Administration. This is PMEL contribution 3475 .

\section{References}

Boyer, T. P., J. I. Antonov, H. Garcia, D. R. Johnson, R. A. Locarnini, A. V. Mishonov, M. T. Pitcher, O. K. Baranova, and I. Smolyar (2006), Introduction, in World Ocean Database 2005 [DVD], NOAA Atlas NESDIS, vol. 60, edited by S. Levitus, chap. 1, pp. 15-37, NOAA, U.S. Gov. Print. Off., Washington D. C. 
Curry, R. (1996), HydroBase-A database of hydrographic profiles and tools for climatological analysis, Tech. Rep. WHOI-96-01, 50 pp., Woods Hole Oceanogr. Inst., Woods Hole, Mass.

Davis, R. E. (2005), Intermediate-depth circulation of the Indian and South Pacific oceans measured by autonomous floats, J. Phys. Oceanogr., 35, 683-707, doi:10.1175/JPO2702.1.

Eden, C., and A. Timmermann (2004), The influence of the Galapagos Islands on tropical temperatures, currents and the generation of tropical instability waves, Geophys. Res. Lett., 31, L15308, doi:10.1029/ 2004GL020060.

Eldin, G. (1983), Eastward flows of the south equatorial central Pacific, J. Phys. Oceanogr., 13, 1461-1467, doi:10.1175/1520-0485(1983) $013<1461$ :EFOTSE $>2.0$. CO; 2 .

Emerson, S., Y. W. Watanabe, T. Ono, and S. Mecking (2004), Temporal trends in apparent oxygen utilization in the upper pycnocline of the North Pacific: 1980-2000, J. Oceanogr., 60, 139-147, doi:10.1023/B: JOCE.0000038323.62130.a0

Fiedler, P. C., and L. D. Talley (2006), Hydrography of the eastern tropical Pacific: A review, Prog. Oceanogr., 69, 143-180, doi:10.1016/j.pocean. 2006.03.008.

Fine, R., K. A. Maillet, K. F. Sullivan, and D. Willey (2001), Circulation and ventilation flux of the Pacific Ocean, J. Geophys. Res., 106, 22,159-22,178, doi:10.1029/1999JC000184.

Firing, E., S. E. Wijffels, and P. Hacker (1998), Equatorial subthermocline currents across the Pacific, J. Geophys. Res., 103, 21,413-21,423, doi:10.1029/98JC01944.

Fuenzalida, R., W. Schneider, J. Garces-Vargas, L. Bravo, and C. Lange (2009), Vertical and horizontal extension of the oxygen minimum zone in the eastern South Pacific Ocean, Deep Sea Res., Part II, 56, 992-1003, doi:10.1016/j.dsr2.2008.11.001

Hanawa, K., and L. D. Talley (2001), Mode waters, in Ocean Circulation and Climate: Observing and Modelling the Global Ocean, edited by G. Siedler, J. Church, and J. Gould, pp. 373-386, Academic, San Diego, Calif., doi:10.1016/S0074-6142(01)80129-7.

Hayes, S. P., J. M. Toole, and L. J. Mangum (1983), Water-mass and transport variability at $110^{\circ} \mathrm{W}$ in the equatorial Pacific, J. Phys. Oceanogr., 13 153-168, doi:10.1175/1520-0485(1983)013<0153:WMATVA $>2.0$. $\mathrm{CO} ; 2$.

Johnson, G. C., and D. W. Moore (1997), The Pacific subsurface countercurrents and an inertial model, J. Phys. Oceanogr., 27, 2448-2459, doi:10.1175/1520-0485(1997)027<2448:TPSCAA $>2.0 . C O ; 2$

Johnson, G. C., B. M. Sloyan, W. S. Kessler, and K. E. McTaggart (2002), Direct measurements of upper ocean currents and water properties across the tropical Pacific during the 1990s, Prog. Oceanogr., 52, 31-61, doi:10.1016/S0079-6611(02)00021-6.

Joos, F., G.-K. Plattner, T. F. Stocker, A. Körtzinger, and D. W. R. Wallace (2003), Trends in marine dissolved oxygen: Implications for ocean circulation changes and the carbon budget, Eos Trans. AGU, 84, 197, doi:10.1029/2003EO210001.

Karstensen, J., L. Stramma, and M. Visbeck (2008), Oxygen minimum zones in the eastern tropical Atlantic and Pacific Oceans, Prog. Oceanogr., 77 331-350, doi:10.1016/j.pocean.2007.05.009.

Keeling, R. F., and H. Garcia (2002), The change in oceanic $\mathrm{O}_{2}$ inventory associated with recent global warming, Proc. Natl. Acad. Sci. U. S. A., 99 7848-7853, doi:10.1073/pnas.122154899.

Kessler, W. S. (2006), The circulation of the eastern tropical Pacific: A review, Prog. Oceanogr., 69, 181-217, doi:10.1016/j.pocean.2006.03.009.

Ledwell, J. R., A. J. Watson, and C. S. Law (1998), Mixing of a tracer in the pycnocline, J. Geophys. Res., 103, 21,499-21,529, doi:10.1029/ 98JC01738.

Luyten, J. R., J. Pedlosky, and H. Stommel (1983), The ventilated thermocline, J. Phys. Oceanogr., 13, 292-309, doi:10.1175/1520-0485(1983) $013<0292$ :TVT $>2.0$. CO 2 .

Matear, R. J., and A. C. Hirst (2003), Long-term changes in dissolved oxygen concentrations in the ocean caused by protracted global warning, Global Biogeochem. Cycles, 17(4), 1125, doi:10.1029/2002GB001997.

McPhaden, M. J., and D. Zhang (2004), Pacific Ocean circulation rebounds, Geophys. Res. Lett., 31, L18301, doi:10.1029/2004GL020727.
Montgomery, R. B., and E. D. Stroup (1962), Equatorial Waters and Currents at $150^{\circ} \mathrm{W}$ in July-August 1952, Johns Hopkins Oceanogr. Stud., vol. 1, 68 pp., Johns Hopkins Press, Baltimore, Md.

Oschlies, A., K. G. Schulz, U. Riebesell, and A. Schmittner (2008), Simulated 21st century's increase in oceanic suboxia by $\mathrm{CO}_{2}$-enhanced biotic carbon export, Global Biogeochem. Cycles, 22, GB4008, doi:10.1029/ $2007 \mathrm{~GB} 003147$.

Paulmier, A., and D. Ruiz-Pino (2009), Oxygen minimum zones (OMZs) in the modern ocean, Prog. Oceanogr., 80,113-128, doi:10.1016/j.pocean. 2008.08.001.

Rowe, G. D., E. Firing, and G. C. Johnson (2000), Pacific equatorial subsurface countercurrent velocity, transport, and potential vorticity, J. Phys. Oceanogr., 30, 1172-1187, doi:10.1175/1520-0485(2000)030<1172. PESCVT $>2.0 . \mathrm{CO} ; 2$

Schott, F. A., J. P. McCreary, and G. C. Johnson (2004), Shallow overturning circulation of the tropical-subtropical oceans, in Earth's Climate: The Ocean-Atmosphere Interaction, Geophys. Monogr. Ser., vol. 147, edited by C. Wang, S.-P. Xie, and J. A. Carton, pp. 261-304, AGU, Washington, D.C.

Sonnerup, R. E., P. D. Quay, and J. L. Bullister (1999), Thermocline ventilation and oxygen utilization rates in the subtropical North Pacific based on CFC distributions during WOCE, Deep Sea Res., Part I, 46, 777-805, doi:10.1016/S0967-0637(98)00092-2.

Stramma, L., P. Brandt, J. Schafstall, F. Schott, J. Fischer, and A. Körtzinger (2008a), The oxygen minimum zone in the North Atlantic south and east of the Cape Verde Islands, J. Geophys. Res., 113, C04014, doi:10.1029/ $2007 J C 004369$.

Stramma, L., G. C. Johnson, J. Sprintall, and V. Mohrholz (2008b), Expanding oxygen-minimum zones in the tropical oceans, Science, 320, 655-658, doi: $10.1126 /$ science. 1153847 .

Tsuchiya, M. (1975), Subsurface countercurrents in the eastern equatorial Pacific Ocean, J. Mar. Res., 33, Suppl., 145-175.

Tsuchiya, M., and L. D. Talley (1998), A Pacific hydrographic section at $88^{\circ} \mathrm{W}$ : Water-property distribution, J. Geophys. Res., 103, 12,899-12,918, doi:10.1029/97JC03415.

von Storch, H., and F. W. Zwiers (1999), The decorrelation time, in Statistical Analysis in Climate Research, chap. 17.1, pp. 371-374, doi:10.1017/ CBO9780511612336.018, Cambridge Univ. Press, Cambridge, U. K.

Whitney, F. A., H. J. Freeland, and M. Robert (2007), Persistently declining oxygen levels in the interior waters of the eastern subarctic Pacific, Prog. Oceanogr., 75, 179-199, doi:10.1016/j.pocean.2007.08.007.

Wijffels, S. E., J. M. Toole, H. L. Bryden, R. A. Fine, W. J. Jenkins, and J. L. Bullister (1996), The water masses and circulation at $10^{\circ} \mathrm{N}$ in the Pacific, Deep Sea Res., Part I, 43, 501-544, doi:10.1016/0967-0637 (96)00006-4.

Wong, A. P. S., and G. C. Johnson (2003), South Pacific eastern subtropical mode water, J. Phys. Oceanogr., 33, 1493-1509, doi:10.1175/1520-0485 (2003)033<1493:SPESMW>2.0.CO;2.

Wunsch, C. (1996), Least squares, in The Ocean Circulation Inverse Problem, chap. 3.3, pp. 113-119, doi:10.1017/CBO9780511629570, Cambridge Univ. Press, Cambridge, U. K.

Wyrtki, K. (1962), The oxygen minima in relation to ocean circulation, Deep Sea Res. Oceanogr. Abstr., 9, 11-23.

Wyrtki, K., and B. Kilonsky (1984), Mean water and current structure during the Hawaii-to-Tahiti shuttle experiment, J. Phys. Oceanogr., 14 242-254, doi:10.1175/1520-0485(1984)014<0242:MWACSD >2.0. $\mathrm{CO} ; 2$

E. Firing, Department of Oceanography, School of Ocean and Earth Science and Technology, University of Hawai'i at Mānoa, Honolulu, HI 96822, USA.

G. C. Johnson and S. Schmidtko, Pacific Marine Environmental Laboratory, NOAA, 7600 Sand Point Way NE, Bldg. 3, Seattle, WA 98115, USA.

L. Stramma, Leibniz-Institut für Meereswissenschaften an der Universität Kiel (IFM-GEOMAR), Düsternbrooker Weg 20, D-24105 Kiel, Germany. (lstramma@ifm-geomar.de) 